MORTALITY, MORBIDITY AND HEALTH STATISTICS 


\title{
Mortality, Morbidity and Health Statistics
}

\author{
Michael Alderson
}

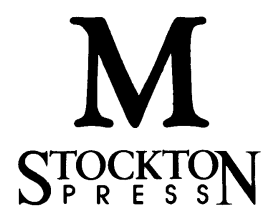


(C) Michael Alderson 1988

Softcover reprint of the hardcover 1st edition 1988 978-0-333-42763-7

All rights reserved. No reproduction, copy or transmission of this publication may be made without written permission.

No paragraph of this publication may be reproduced, copied or transmitted save with written permission or in accordance with the provisions of the Copyright Act 1956 (as amended), or under the terms of any licence permitting limited copying issued by the Copyright Licensing Agency, 33-4 Alfred Place, London WC1E 7DP.

Any person who does any unauthorised act in relation to this publication may be liable to criminal prosecution and civil claims for damages.

First published 1988

Published in the UK by

The Macmillan Press Ltd

Brunel Road, Houndmills, Basingstoke, Hampshire RG21 2XS

ISBN 978-1-349-09070-9 ISBN 978-1-349-09068-6 (eBook)

DOI 10.1007/978-1-349-09068-6

Published in the United States and Canada by Stockton Press

15 East 26th Street, New York, NY 10010

ISBN 978-0-935859-31-7

Typeset by Latimer Trend \& Company Ltd Plymouth 


\section{Contents}

Preface $\quad$ xv

1 INTRODUCTION 1

1.1 Background 1

1.1.1 Need for, demand for and use of health services 1

1.2 Incidence, prevalence and mortality 2

1.3 Confidentiality J

1.3.1 Background 5

1.3.2 Sources of the data 5

1.3.3 Legal or other definition of permitted use 5

1.3.4 Consent to release of data for use 6

1.3.5 The role of ethical committees 6

1.3.6 Security 6

1.3.6.1 Physical security 7

1.3.7 Confidentiality and use of medical information 7

1.3.8 Release 8

1.3.9 Public attitudes to confidentiality of medical data $\quad 8$

1.3.10 Staff guidelines 9

1.3.11 Principles or codes of practice 9

$\begin{array}{lr}\text { 1.3.12 Laws on confidentiality } & 10\end{array}$

1.3.12.1 Data Protection Act, $1984 \quad 10$

1.4 Population statistics 10

$\begin{array}{ll}\text { 1.4.1 National population censuses } & 10\end{array}$

1.4.1.1 Method of censuses $\quad 12$

1.4.1.2 Validity of censuses $\quad 12$

$\begin{array}{ll}\text { 1.4.2 Annual population estimates } & 13\end{array}$

1.4.2.1 Validity of population estimates 13

1.5 Classification of disease 14

1.5.1 International Classification of Disease (ICD) revision changes 15

1.5.2 The role of a nomenclature 16

$\begin{array}{ll}\text { 1.5.3 The role of a glossary } & 17\end{array}$

$\begin{array}{ll}1.6 \text { Coding } & 18\end{array}$

$\begin{array}{lll}1.7 & \text { Validity } & 18\end{array}$ 
vi Contents

$\begin{array}{llr}1.8 & \text { Statistics } & 19\end{array}$

$\begin{array}{lll}\text { 1.8.1 Numbers and rates } & 19\end{array}$

1.8.2 Do differences in numbers of events or event rates

1.9 Inference 21

$\begin{array}{lll}\text { 1.9.1 Statistical technique } & 21\end{array}$

$\begin{array}{ll}\text { 1.9.2 Multiple comparisons } & 22\end{array}$

1.9.3 Derivation of inferences 22

$\begin{array}{ll}1.10 \text { Release of material } & 24\end{array}$

\begin{tabular}{ll}
1.10 .1 & Uses of event data \\
\hline
\end{tabular}

$\begin{array}{ll}1.11 \text { Bibliography } & 26\end{array}$

2 MORTALITY STATISTICS 28

$\begin{array}{lll}2.1 \text { Background } & 28\end{array}$

$\begin{array}{ll}2.1 .1 & \text { Occupational mortality statistics } \\ 2.1 .29\end{array}$

$\begin{array}{lll}2.1 .2 & \text { Areal analysis } & 31\end{array}$

$\begin{array}{ll}2.2 \text { Method } & 34\end{array}$

$\begin{array}{lll}2.2 .1 & \text { Source } & 34\end{array}$

2.2.1.1 Registration in England and Wales 34

2.2.1.2 Registration in other countries $\quad 35$

2.2.1.3 Lay reporting 36

$\begin{array}{lll}\text { 2.2.2 Classification } & 36\end{array}$

2.2.2.1 Classification of the cause of death 36

$\begin{array}{ll}\text { 2.2.2.2 Classification of area statistics } & 37\end{array}$

$\begin{array}{lll}2.2 .3 \text { Coding } & 40\end{array}$

2.2.3.1 Coding of the cause of death 40

2.2.3.2 Multiple cause coding (MCC) 41

2.2.4 Validity of mortality statistics 45

2.2.4.1 General issues of validity 46

2.2.4.2 Accuracy of the cause of death 47

2.2.4.3 Comparison of clinical and autopsy diagnosis $\quad 48$

2.2.4.4 Comparison of clinical history and death certificate 50

$\begin{array}{lll}2.2 .4 .5 & \text { Certification } & 52\end{array}$

2.2.4.6 Infant mortality $\quad 57$

2.2.4.7 Validity of occupational mortality statistics $\quad 59$

2.2.4.8 Validity of area mortality 62

2.2.4.9 Time 66

$\begin{array}{lll}2.2 .5 & \text { Linkage of mortality records } & 67\end{array}$

$\begin{array}{lll}\text { 2.2.6 Statistical method } & 68\end{array}$

2.2.6.1 Handling perinatal mortality statistics 68

$\begin{array}{ll}\text { 2.2.6.2 Standardisation } & 70\end{array}$

2.2.6.3 Proportional mortality analysis $\quad 75$

$\begin{array}{lll}\text { 2.2.6.4 Collation studies } & 77\end{array}$ 
2.2.6.5. Cohort analysis

Statistical distinction of cohort and period change

2.2.6.6 Life tables

Calculation of life table

85

Future years of life lost $\quad 87$

$\begin{array}{ll}\text { 2.2.6.7 Projection } & 89\end{array}$

$\begin{array}{lll}2.2 .7 & \text { Presentation } & 94\end{array}$

2.2.7.1 Tables, Histograms or Pie charts? 94

2.2.7.2 Areal presentation 94

$\begin{array}{ll}2.2 .7 .3 \text { Collation } & 99\end{array}$

$\begin{array}{lll}2.2 .7 .4 & \text { Trends } & 100\end{array}$

$\begin{array}{lll}2.2 .8 & \text { Publications } & 101\end{array}$

2.2.8.1 World Health Organization 101

2.2.8.2 United Nations 103

2.2.8.3 National publications $\quad 104$

$\begin{array}{ll}2.2 .8 .4 & \text { Other publications } \\ & 104\end{array}$

$\begin{array}{lll}2.3 & \text { Uses of mortality statistics } & 105\end{array}$

2.3.1 Advantages and disadvantages of mortality statistics 106

$\begin{array}{lll}2.3 .2 & \text { Person } & 108\end{array}$

2.3.2.1 Uses of occupational mortality statistics $\quad 109$

2.3.2.2 Migrants 111

$\begin{array}{lll}2.3 .3 & \text { Place } & 114\end{array}$

2.3.3.1 The aim of geographic comparisons 114

2.3.3.2 Aetiological clues 114

2.3.3.3 Aspects of interpretation 115

2.3.3.4 Actual benefits 116

$\begin{array}{lll}2.3 .4 & \text { Time } & 118\end{array}$

$\begin{array}{lll}2.3 .4 .1 & \text { Season } & 120\end{array}$

2.3.5 Monitoring the public health: what or where is the $\begin{array}{ll}\text { problem? } & 125\end{array}$

$\begin{array}{ll}\text { 2.3.6 Resource allocation } & 130\end{array}$

2.3.7 Models 131

$\begin{array}{llr}2.4 & \text { Bibliography } & 132\end{array}$

3 LEGAL ABORTIONS 168

$\begin{array}{lll}3.1 \text { Background } & 168\end{array}$

$\begin{array}{ll}3.2 \text { Method } & 168\end{array}$

$\begin{array}{lll}3.2 .1 & \text { Source } & 168\end{array}$

3.2.1.1 Great Britain 168

3.2.1.2 Other countries 169

$\begin{array}{lll}3.2 .2 & \text { Validity } & 169\end{array}$

$\begin{array}{lll}3.2 .3 & \text { Statistical aspects } & 170\end{array}$

$\begin{array}{lll}3.2 .4 & \text { Publications } & 171\end{array}$ 
viii Contents

$\begin{array}{lll}3.3 & \text { Uses of abortion statistics } & 172\end{array}$

$\begin{array}{lll}\text { 3.3.1 Descriptive statistics } & 172\end{array}$

3.3.1.1 Person 172

$\begin{array}{lll}3.3 .1 .2 & \text { Place } & 173\end{array}$

$\begin{array}{lll}3.3 .1 .3 & \text { Time } & 174\end{array}$

$\begin{array}{lll}\text { 3.3.2 Medical care studies } & 177\end{array}$

$\begin{array}{llr}3.4 & \text { Bibliography } & 179\end{array}$

4 CANCER REGISTRATION 181

$\begin{array}{lll}4.1 & \text { Background } & 181\end{array}$

$\begin{array}{ll}4.2 \text { Method } & 183\end{array}$

$\begin{array}{lll}\text { 4.2.1 Sources of data } & 183\end{array}$

4.2.1.1 The national scheme for England and Wales 183

4.2.1.2 Other countries' systems 184

4.2.1.3 The need for 100 per cent national coverage 184

4.2.1.4 Items to be recorded 185

$\begin{array}{lll}\text { 4.2.1.5 Survival } & 186\end{array}$

4.2.1.6 The role of national, regional and local registries 188

4.2.2 Classification and coding 189

$\begin{array}{lll}4.2 .3 & \text { Validity } & 190\end{array}$

4.2.3.1 Completeness of registration $\quad 190$

$\begin{array}{ll}\text { 4.2.3.2 Validity of items } & 192\end{array}$

$\begin{array}{lll}\text { 4.2.3.3 Survival } & 193\end{array}$

$\begin{array}{lll}\text { 4.2.4 Record linkage } & 193\end{array}$

4.2.5 Statistical methods 194

4.2.5.1 Standardisation $\quad 194$

$\begin{array}{ll}\text { 4.2.5.2 Standardisation without an adequate } & \begin{array}{l}\text { Stanom } \\ \text { denominator }\end{array}\end{array}$

4.2.5.3 Survival from cancer 196

$\begin{array}{lll}\text { 4.2.5.4 Person-years at risk } & 197\end{array}$

4.2.5.5 Projection of cancer incidence 198

4.2.5.6 Space-time clustering 200

4.2.5.7 Probability of developing cancer 202

$\begin{array}{lll}\text { 4.2.6 Presentation } & 202\end{array}$

4.2.7 Publications $\quad 202$

4.2.7.1 Incidence statistics 202

$\begin{array}{lll}\text { 4.2.7.2 Survival } & 205\end{array}$

$\begin{array}{lll}4.3 & \text { Use } & 205\end{array}$

$\begin{array}{lll}\text { 4.3.1 Person } & 205\end{array}$

$\begin{array}{lll}\text { 4.3.1.1 Occupation } & 207\end{array}$

$\begin{array}{lll}4.3 .2 & \text { Place } & 207\end{array}$

$\begin{array}{lll}4.3 .3 & \text { Time } & 209\end{array}$

$\begin{array}{lll}\text { 4.3.3.1 Survival analyses } & 209\end{array}$ 
$\begin{array}{lll}\text { 4.3.4 Space-time clustering } & 210\end{array}$

$\begin{array}{ll}\text { 4.3.5 Medical care aspects } & 211\end{array}$

$\begin{array}{lll}\text { 4.3.6 Record linkage } & 212\end{array}$

4.3.6.1 Ad hoc linkage of data 212

$\begin{array}{ll}\text { 4.3.7 Advantages and disadvantages } & 213\end{array}$

$\begin{array}{lll}4.4 & \text { Bibliography } & 213\end{array}$

5 CONGENITAL MALFORMATIONS 216

$\begin{array}{lll}5.1 \text { Background } & 216\end{array}$

$\begin{array}{ll}5.2 \text { Method } & 217\end{array}$

$\begin{array}{lll}5.2 .1 & \text { Source } & 217\end{array}$

5.2.1.1 Routine sources of international statistics 218

5.2.1.2 Other sources of data 222

$\begin{array}{ll}\text { 5.2.2 Classification/coding } & 223\end{array}$

5.2.3 Validity 223

5.2.3.1 Errors in the basic data 223

5.2.3.2 Bias 226

5.2.3.3 Effect of small numbers 227

5.2.3.4 Improving the quality of the data 227

$\begin{array}{lll}5.2 .4 & \text { Linkage } & 228\end{array}$

$\begin{array}{lll}\text { 5.2.5 Statistical method } & 228\end{array}$

5.2.5.1 Incidence or prevalence statistics 228

5.2.5.2 Analyses performed 229

5.2.5.3 Collation studies 230

$\begin{array}{lll}\text { 5.2.6 Publications } & 231\end{array}$

$\begin{array}{lll}5.3 \text { Uses } & 232\end{array}$

$\begin{array}{ll}\text { 5.3.1 Advantages and disadvantages } & 232\end{array}$

$\begin{array}{lll}5.3 .2 & \text { Person } & 233\end{array}$

5.3.2.1 Occupation 233

$\begin{array}{lll}5.3 .3 & \text { Place } & 234\end{array}$

$\begin{array}{lll}5.3 .4 & \text { Time } & 234\end{array}$

5.3.5 Monitoring the Public Health 236

$\begin{array}{ll}\text { 5.3.6 Special studies } & 237\end{array}$

$\begin{array}{lll}5.4 & \text { Bibliography } & 238\end{array}$

6 HOSPITAL DISCHARGE STATISTICS 240

$\begin{array}{lll}6.1 \text { Background } & 240\end{array}$

6.1.1 Maternity patients 241

$\begin{array}{lll}\text { 6.1.2 Psychiatric patients } & 242\end{array}$

6.1.3 Out-patient, and Accident and Emergency care 243

6.2 Method 243

$\begin{array}{lll}\text { 6.2.1 Source } & 244\end{array}$

6.2.1.1 England and Wales 244

6.2.1.2 International 246 
x Contents

6.2:2 Classification and coding 251

$\begin{array}{lll}6.2 .3 & 252\end{array}$

6.2.3.1 Is the record entered into the system? 253

6.2.3.2 The accuracy of reporting of the discharge diagnosis 253

6.2.3.3 Identification of deaths 256

6.2.3.4 The validity of the linkage items 256

6.2.3.5 Coding 257

6.2.3.6 Does the patient require admission? 257

6.2.3.7 Validity of data on psychiatric patients 258

6.2.3.8 Future action 258

6.2.4 Linkage of repeat events 258

$\begin{array}{lll}6.2 .5 & \text { Statistics } & 259\end{array}$

6.2.5.1 Length of stay $\quad 259$

6.2.5.2 Projection 260

$\begin{array}{lll}\text { 6.2.6 Presentation } & 261\end{array}$

6.2.7 Publications $\quad 261$

6.2.7.1 Pyschiatric publications 261

$\begin{array}{lll}6.3 & \text { Uses } & 263\end{array}$

$\begin{array}{lll}\text { 6.3.1 General issues } & 263\end{array}$

$\begin{array}{lll}\text { 6.3.2 Person } & 264\end{array}$

6.3.2.1 Psychiatric patients 264

6.3.2.2 Migrants 264

$\begin{array}{lll}6.3 .3 & \text { Place } & 267\end{array}$

$\begin{array}{lll}\text { 6.3.3.1 Psychiatric patients } & 269\end{array}$

$\begin{array}{lll}6.3 .4 & \text { Time } & 270\end{array}$

$\begin{array}{lll}\text { 6.3.4.1 Psychiatric patients } & 272\end{array}$

$\begin{array}{lll}6.3 .5 & \text { Collation } & 272\end{array}$

$\begin{array}{lll}\text { 6.3.6 Record linkage } & 273\end{array}$

6.3.6.1 Registers $\quad 274$

$\begin{array}{lll}\text { 6.3.7 Medical care studies } & 275\end{array}$

$\begin{array}{lll}\text { 6.3.7.1 Operations } & 277\end{array}$

$\begin{array}{lll}\text { 6.3.7.2 Maternity } & 278\end{array}$

$\begin{array}{lll}\text { 6.3.7.3 Psychiatric patients } & 278\end{array}$

$\begin{array}{ll}\text { 6.3.8 Life table applications } & 279\end{array}$

$\begin{array}{lll}6.4 & \text { Bibliography } & 280\end{array}$

7 INFECTIOUS DISEASE STATISTICS 285

$\begin{array}{lll}7.1 \text { Background } & 285\end{array}$

$\begin{array}{lll}7.2 \text { Method } & 286\end{array}$

$\begin{array}{lll}7.2 .1 & \text { Source } & 287\end{array}$

7.2.1.1 Statutory notification 287

7.2.1.2 General practice reporting 287

$\begin{array}{lll}\text { 7.2.1.3 Laboratory data } & 289\end{array}$ 
$\begin{array}{lll}7.2 .2 & \text { Validity } & 290\end{array}$

$\begin{array}{lll}7.2 .3 & \text { Statistics } & 295\end{array}$

7.2.3.1 Models 295

$\begin{array}{ll}\text { 7.2.3.2 Collation } & 296\end{array}$

$\begin{array}{lll}7.2 .4 & \text { Presentation } & 296\end{array}$

$\begin{array}{lll}7.2 .5 & \text { Publications } & 297\end{array}$

7.2.5.1 England and Wales 297

7.2.5.2 International 299

$\begin{array}{lll}7.3 \text { Uses } & 300\end{array}$

$\begin{array}{lll}\text { 7.3.1 General issues } & 300\end{array}$

$\begin{array}{lll}7.3 .2 & \text { Person } & 300\end{array}$

$\begin{array}{lll}7.3 .3 & \text { Place } & 301\end{array}$

$\begin{array}{lll}7.3 .4 & \text { Time } & 304\end{array}$

$\begin{array}{lll}7.3 .5 & \text { Collation } & 307\end{array}$

$\begin{array}{lll}7.3 .6 & \text { Medical care } & 308\end{array}$

$\begin{array}{lll}7.4 & \text { Bibliography } & 309\end{array}$

8 MORBIDITY STATISTICS FROM GENERAL PRACTICE $\quad 312$

$\begin{array}{lll}8.1 & \text { Background } & 312\end{array}$

$\begin{array}{lll}8.2 \text { Method } & 314\end{array}$

$\begin{array}{lll}\text { 8.2.1 Source } & 314\end{array}$

8.2.1.1 England and Wales $\quad 314$

8.2.1.2 International studies 318

$\begin{array}{ll}\text { 8.2.2 Classification/coding } & 322\end{array}$

8.2.3 Validity of material 324

8.2.3.1 How typical are the participating doctors or their patients? 324

8.2.3.2 Identifying the patients at risk of consulting 324

8.2.3.3 Who contacts their ductor? 325

8.2.3.4 The validity of the recorded information 326

8.2.3.5 Overview on validity 327

$\begin{array}{lll}8.2 .4 & \text { Linkage } & 327\end{array}$

$\begin{array}{lll}8.2 .5 & \text { Statistical aspects } & 328\end{array}$

$\begin{array}{lll}\text { 8.2.6 Publications } & 328\end{array}$

8.2.6.1 England and Wales $\quad 328$

8.2.6.2 International 329

$\begin{array}{lll}8.3 & \text { Uses } & 331\end{array}$

$\begin{array}{lll}\text { 8.3.1 General aspects } & 331\end{array}$

8.3.2 Persons $\quad 332$

$\begin{array}{lll}\text { 8.3.3 Place } & 332\end{array}$

8.3.4 Time 333

8.3.5 The extent of clinical problems 335

$\begin{array}{lll}\text { 8.3.6 Medical care studies } & 335\end{array}$

$\begin{array}{lll}\text { 8.3.7 Prescribing } & 337\end{array}$ 
xii Contents

8.4 Bibliography

9 SICKNESS ABSENCE AND OCCUPATIONAL DISEASE $\begin{array}{ll}\text { STATISTICS } & 338\end{array}$

$\begin{array}{lll}9.1 \text { Background } & 338\end{array}$

$\begin{array}{lll}9.2 \text { Method } & 338\end{array}$

$\begin{array}{lll}\text { 9.2.1 Source } & 338\end{array}$

9.2.1.1 Sickness absence from Social Security records 338

9.2.1.2 Statistics from industry 339

$\begin{array}{lll}9.2 .2 & \text { Validity } & 340\end{array}$

$\begin{array}{lll}\text { 9.2.3 Statistical applications } & 341\end{array}$

9.2.3.1 Collation 341

$\begin{array}{lll}\text { 9.2.3.2 Cusums } & 342\end{array}$

$\begin{array}{lll}\text { 9.2.4 Publications } & 343\end{array}$

9.2.4.1 England and Wales routine data 343

9.2.4.2 Statistics from industry 343

9.2.4.3 Other national statistics 344

$\begin{array}{lll}9.3 \text { Use } & 345\end{array}$

9.3.1 General aspects $\quad 345$

$\begin{array}{lll}\text { 9.3.2 Person } & 345\end{array}$

$\begin{array}{lll}9.3 .3 & \text { Place } & 346\end{array}$

$\begin{array}{lll}9.3 .4 & \text { Time } & 346\end{array}$

9.3.5 Public health issues $\quad 348$

$\begin{array}{lll}\text { 9.3.6 Statistics from industry } & 348\end{array}$

$\begin{array}{lll}\text { 9.3.7 Research applications } & 348\end{array}$

$\begin{array}{lll}9.4 & \text { Bibliography: national publications } & 348\end{array}$

10 HEALTH SURVEYS AT NATIONAL LEVEL 350

$\begin{array}{lll}10.1 \text { Background } & 350\end{array}$

$\begin{array}{lll}10.2 \text { Method } & 352\end{array}$

$\begin{array}{lll}\text { 10.2.1 Source } & 352\end{array}$

10.2.1.1 Choice of study population 352

10.2.1.2 Sampling 353

10.2.1.3 Methods of data collection 354

10.2.1.4 Categories of data 355

$\begin{array}{lll}\text { 10.2.2 Classification } & 355\end{array}$

$\begin{array}{lll}10.2 .3 & \text { Validity } & 356\end{array}$

10.2.3.1 Response 356

10.2.3.2 Validity of information collected from

$\begin{array}{lll}\text { 10.2.4 Linkage } & 361\end{array}$

$\begin{array}{lll}\text { 10.2.5 Statistics } & 361\end{array}$

10.2.5.1 How large a study is required? 361

10.2.5.2 Sampling errors 363 
10.2.5.3 Measures of validity

10.2.5.4 Life tables of disability 364

10.2.5.5 Standardisation 365

10.2.6 National publications 365

$\begin{array}{lll}10.3 \text { Uses } & 379\end{array}$

$\begin{array}{lll}\text { 10.3.1 General } & 379\end{array}$

$\begin{array}{lll}10.3 .2 & \text { Person } & 379\end{array}$

$\begin{array}{lll}10.3 .3 & \text { Place } & 380\end{array}$

$\begin{array}{lll}10.3 .4 & \text { Time } & 381\end{array}$

10.3.5 Monitoring the public health 383

10.4 Bibliography 384

11 MONITORING THE PUBLIC HEALTH 387

11.1 Introduction 387

11.2 Monitoring and surveillance 387

11.2.1 Classes of data required 388

11.3 Health indicators 389

11.3.1 Validity of techniques 391

11.3.2 Statistical methods $\quad 392$

11.4 Outcome measures 392

11.4.1 Overall measures 395

11.4.1.1 Expectation of life 395

11.4.1.2 Mortality patterns 395

11.4.1.3 Morbidity patterns 397

11.4.1.4 Well-being 403

11.4.2 Prevention 403

11.4.2.1 Congenital malformations 403

11.4.2.2 Fetal wastage 403

11.4.2.3 Infant morbidity 404

11.4.2.4 Surveillance of infectious disease $\quad 404$

11.4.2.5 Cancer 405

11.4.2.6 Other conditions 407

11.4.3 Markers of risk 407

11.4.4 Results of treatment 408

11.4.4.1 Adverse drug reactions (ADRs) 408

11.4.4.2 Case fatality 416

11.4.4.3 Pregnancy and the neonate 416

$\begin{array}{lll}11.4 .4 .4 & \text { Survival } & 417\end{array}$

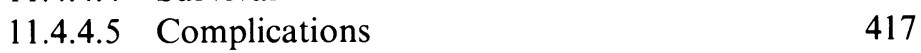

11.4.4.6 Patient satisfaction $\quad 417$

11.5 Monitoring the impact of the environment on health 419

11.5.1 Some general issues 419

$\begin{array}{ll}\text { 11.5.2 The use of routine data } & 420\end{array}$ 
xiv Contents

11.5.3 Can routine data identify an environmental problem? 422

11.5.4 Examples of public concern 422

11.5.5 The need for analytic studies 423

$\begin{array}{lll}11.6 & \text { Occupation } & 423\end{array}$

11.6.1 Occupational monitoring systems $\quad 424$

$\begin{array}{lll}11.7 & \text { Registers } & 426\end{array}$

11.7.1 Action registers $\quad 426$

$\begin{array}{lll}\text { 11.7.2 Information registers } & 427\end{array}$

$\begin{array}{lll}\text { 11.7.3 Examples of registers } & 427\end{array}$

11.7.3.1 Cardiac surgery 428

11.7.3.2 Diabetes 428

11.7.3.3 Genetic Disorders 428

11.7.3.4 Handicap 429

11.7.3.5 Mental handicap 429

11.7.3.6 Myocardial infarction $\quad 429$

11.7.3.7 Psychiatric Patients 431

11.8 Conditions requiring multiple sources of information 431

11.9 Conditions for which routine data are inadequate 433

11.10 Conclusions $\quad 433$

11.10.1 General requirements $\quad 435$

$\begin{array}{ll}11.11 \text { Bibliography } & 438\end{array}$

References $\quad 441$

Index $\quad 491$ 


\section{Preface}

The aim of this book is first to provide a comprehensive guide to the users of mortality statistics and second to list various sources of morbidity statistics, on abortion, cancer registration, congenital malformation notification, hospital inpatients, morbidity treated in general practice, notification of infectious disease, sickness absence and indicators of morbidity from surveys. In addition to the inclusion of chapters on each of these nine topics, the book begins with a consideration of some of the general method issues, and ends with a consideration of the relative role of routine versus ad hoc collection of data (especially via ad hoc surveys). Each topic-chapter contains material on specific method issues relevant to the particular topic; emphasis is placed on the source of the basic data, the validity of the material, the statistical techniques most appropriate for handling the material, ways of presenting the statistics, the publications of international material and the various uses to which the results may be put. For each main category of use, one or more examples are given, usually accompanied by tables or figures of actual data. These examples have been chosen primarily to provide clear examples of the various uses, but they also attempt to cover a wide range of diseases and include material from various countries. It was not possible to ensure complete coverage of all conditions and all countries, as the selection had to be governed by what was available, and it also needed to be suitable to illustrate the method aspects.

The book should be of value to (1) those responsible for handling routine mortality and morbidity statistics in regional and national offices of vital statistics or health statistics and (2) users of routine data, such as epidemiologists, other medical staff, statisticians, and those involved in health-care management.

It must be emphasised that the book does not include material on (1) staffing, (2) facilities (hospitals, beds, clinics, major equipment inventories) or (3) costs of health care. These are very different sets of statistics, generally of interest to a different group from those concerned with studying mortality or morbidity. The sources, problems of use, types of application and statistical techniques required are all different from those covered in this book. They were therefore considered inappropriate for inclusion.

In a much more limited, very different and now somewhat dated fashion, some of the material included here appeared in two earlier works-Routine Central Government Health Statistics (Alderson, 1974) and Health Surveys and 
xvi Preface

Related Studies (Alderson and Dowie, 1979). I am most grateful to Professor Derek Maunder, who invited me to provide these contributions to the series that he was editing on UK Statistical Sources. As indicated in the previous paragraph, I have steered clear of the area that was the particular field of my collaborator in the second work, Mrs Robin Dowie. In various capacities I have been involved in work relevant to the topics of this book since 1962. I am most grateful to the late Professor Robert Wofinden and Dr Wynne Griffith, who started me on this path, and the many colleagues who have helped me along the way since then. It would be invidious to identify any other individual from the many who have advised me over the past 25 years.

This book is dedicated to my wife, who has struggled on while I finished my eighth such work in what should have been our spare time together.

Southampton, 1988

M.R.A.

\section{Publisher's announcement}

It is with regret that we record the sudden death of Dr Alderson as this book was going to press. We offer our condolences to his family. 